\title{
PENERAPAN ART THERAPY UNTUK MENGURANGI KECEMASAN MAHASISWA USIA EMERGING ADULTHOOD PADA MASA PANDEMI
}

\author{
Bryan Tjugito $^{1}$, Monty P. Satiadarma ${ }^{2}$, Untung Subroto ${ }^{3}$ \\ ${ }^{1}$ Magister Psikologi, Universitas Tarumanagara Jakarta \\ Email: bryan.717182007@stu.untar.ac.id \\ ${ }^{2}$ Fakultas Psikologi, Universitas Tarumanagara Jakarta \\ Email: monty_satiadarma@yahoo.com \\ ${ }^{3}$ Fakultas Psikologi, Universitas Tarumanagara Jakarta \\ Email: untungs@fpsi.untar.ac.id
}

Masuk : 01-04-2021, revisi: 22-07-2021, diterima untuk diterbitkan : 22-07-2021

\begin{abstract}
Coronavirus disease 2019 (covid-19) has made major changes for the country in various sectors, one of which is education. Changes that occur in the education sector are in the form of a face-to-face learning system into an online learning system. This change creates anxiety among students. Some of the effects of this anxiety include sleeping difficulties, stomach disorders, and irregular menstrual cycles. Art therapy has been found to significantly reduce the severity of anxiety. Thus, this study aims to determine whether the application of art therapy can reduce anxiety symptoms in students aged 18-25 years who are doing online learning during a pandemic. The research design used in this study was a quasi-experimental. The sampling technique is non-probability sampling by providing a state-trait anxiety inventory (STAI) measurement tool to see the level of anxiety and participants are selected if they are included in the moderate or high category. Six of the twelve participants were selected (4 participants with a moderate level and 2 participants with a high level) and the researcher took individual data by interviewing to help researchers in building rapport with participants. After six intervention sessions, it was found that there was a decrease in anxiety levels, four participants were at low anxiety levels.
\end{abstract}

Keywords: Anxiety, art therapy, pandemic, university student

\begin{abstract}
ABSTRAK
Coronavirus disease 2019 (covid-19) memberikan perubahan yang besar bagi negara diberbagai sektor, salah satunya pendidikan. Perubahan yang terjadi pada sektor pendidikan berupa sistem belajar tatap muka menjadi sistem belajar daring. Perubahan ini menimbulkan rasa cemas pada para pelajar, tidak terkecuali mahasiswa. Beberapa dampak dari rasa cemas ini berupa sulit tidur, gangguan lambung, hingga siklus haid tidak teratur. Art therapy ditemukan dapat mengurangi kecemasan secara signifikan. Sehingga, penelitian ini memiliki tujuan untuk mengetahui apakah penerapan art therapy dapat mengurangi simtom kecemasan pada mahasiswa berusia 18-25 tahun yang melakukan pembelajaran daring pada masa pandemi. Desain penelitian yang digunakan dalam penelitian ini adalah kuasi eksperimen. Teknik pengambilan sampel non-probability sampling dengan memberikan alat ukur state-trait anxiety inventory (STAI) untuk melihat tingkat kecemasan dan partisipan diseleksi apabila termasuk dalam golongan moderate atau high. Enam dari dua belas partisipan terpilih (4 partisipan dengan tingkat moderate dan 2 partisipan dengan tingkat high) dan peneliti melakukan pengambilan data individual dengan wawancara untuk membantu peneliti dalam membangun rapport dengan partisipan. Setelah enam sesi intervensi, ditemukan bahwa terdapat penurunan pada tingkat kecemasan, empat partisipan berada pada tingkat kecemasan low.
\end{abstract}

Kata Kunci: Art therapy, kecemasan, mahasiswa, pandemi

\section{PENDAHULUAN}

\section{Latar Belakang}

Coronavirus disease 2019 (covid-19) adalah sebuah virus baru yang ditemukan di Wuhan, Tiongkok pada akhir bulan Desember 2019, dan di Indonesia sendiri virus ini pertama kali muncul pada 2 Maret 2020 (Akbar, 2020). Covid-19 sudah memberikan dampak yang cukup besar bagi negara dalam berbagai sektor seperti ekonomi (Afrianto, 2020; Huzaini, 2020; Ibrahim, 2020; Prayoga, 2020; Zuraya, 2020), pariwisata (Kurnia, 2020; Sugihamreta, 2020), kesehatan (Afrianto, 2020; Intan, 2020), hingga pendidikan (Nuryana, 2020). Perubahan yang paling dirasakan dari sektor pendidikan adalah berubahnya sistem belajar tatap muka menjadi sistem 
belajar daring. Perubahan ini diambil dalam usaha menekan angka penyebaran virus di masyarakat. Namun demikian, hal tersebut justru menimbulkan kecemasan bagi para pelajar, tidak terkecuali mahasiswa.

Pada umumnya, mahasiswa berada pada usia kurang lebih 18 tahun ketika awal mereka menempuh pendidikan di jenjang universitas. Hal ini menunjukkan bahwa mereka sedang berada pada tahap perkembangan emerging adulthood di mana biasanya pada usia ini individu cenderung memiliki banyak stressor, terutama stressor yang berkaitan dengan pendidikan (Edwards et al., 2001; Nonis et al. dalam Schwartz et al., 2018) seperti tuntutan akademis yang tinggi. Sehingga hal ini turut menjadi salah satu faktor pemicu munculnya kecemasan, yang jika tidak diatasi dapat mengarah pada depresi (Herberman, Fullerton, \& Ursano, 2013) hingga pengambilan langkah maladaptif untuk mengatasi kecemasan yang dirasakan (Servaty-Seib \& Taub, 2010).

Spielberger (1966) menjelaskan bahwa kecemasan merupakan suatu reaksi emosional yang tidak menyenangkan terhadap bahaya yang nyata atau imajiner, serta dibedakan menjadi dua jenis, yaitu state anxiety dan trait anxiety. State anxiety merupakan sebuah reaksi emosional yang terdiri dari perasaan tidak menyenangkan, kemudian secara sadar merasakan adanya ketegangan dan ketakutan dengan aktivitas terkait, dan biasanya kecemasan ini dapat meningkat pada waktuwaktu tertentu. Sedangkan trait anxiety merupakan karakteristik pencemas individu yang akan memengaruhi intensitas kecemasan pada saat merespon berbagai macam situasi. Biasanya individu dengan trait anxiety yang lebih tinggi, mereka akan lebih pencemas dibandingkan dengan individu dengan trait anxiety yang lebih rendah. Trait anxiety ini cenderung menetap pada diri individu.

Art therapy merupakan suatu teknik terapi yang menggunakan media seni, proses kreatif, dan hasil seni untuk mengeksplorasi perasaan, konflik emosi, meningkatkan kesadaran diri, mengontrol perilaku dan adiksi, mengembangkan kemampuan sosial, meningkatkan orientasi realitas, mengurangi kecemasan, dan meningkatkan penghargaan diri (American Art Therapy Association, 2013). Berbeda dengan Rappaport (2009) yang menjelaskan art therapy sebagai suatu teknik terapi yang mencakup seni visual, proses kreatif, dan psikoterapi guna meningkatkan kesejahteraan individu baik secara emosional, kognitif, fisik, maupun spiritual. Dengan demikian dapat dikatakan bahwa art therapy merupakan suatu teknik terapi yang melibatkan proses kreatif guna meningkatkan kesejahteraan individu. Ganim (1999) mengatakan art therapy merupakan sarana yang tepat dalam membantu individu untuk mengungkapkan emosi terdalam yang seringkali tidak disadari atau sulit diungkapkan melalui kata-kata, dan kecemasan merupakan emosi yang sulit untuk diungkapkan dengan kata-kata. Selain itu, Ganim (1999) juga menjelaskan bahwa yang menjadi penting dalam kesuksesan terapi ini bukanlah nilai estetika yang dibuat, melainkan proses yang dijalani berupa insight yang diperoleh individu selama menggambar.

Berdasarkan kajian literatur yang sudah dibahas, diketahui bahwa mahasiswa yang berada pada tahap perkembangan emerging adulthood cenderung sudah memiliki stressor cukup besar yang diperoleh dari pendidikan. Hal ini kemudian diperparah dengan perubahan sistem belajar karena pandemi covid-19, sehingga kecemasan pada mahasiswa cenderung mengalami peningkatan. Hal ini membuat diperlukannya sebuah intervensi psikologis pada mahasiswa tersebut.

Kecenderungan individu yang sulit mengungkapkan emosi ketika mengalami kecemasan membuat art therapy menjadi suatu sarana intervensi yang dapat membantu mahasiswa dalam mengungkapkan emosi mereka guna mengurangi rasa cemas. Selain itu, art therapy juga efektif dalam membantu menurunkan simtom kecemasan (Duong et al., 2017). Dengan demikian, peneliti 
ingin melihat apakah intervensi menggunakan art therapy dapat mengurangi kecemasan mahasiswa pada usia emerging adulthood yang mengikuti pembelajaran daring pada masa pandemi.

\section{Rumusan masalah}

Rumusan masalah dalam penelitian ini adalah "Apakah penerapan art therapy dapat membantu mengurangi kecemasan mahasiswa pada usia emerging adulthood yang mengikuti pembelajaran daring pada masa pandemi?"

\section{Hipotesis}

Penerapan art therapy dapat membantu mengurangi kecemasan mahasiswa pada usia emerging adulthood yang mengikuti pembelajaran daring pada masa pandemi.

\section{METODE PENELITIAN}

\section{Partisipan}

Sesi dilakukan untuk enam partisipan mahasiswa dan dilakukan secara individual dalam waktu dan tempat yang berbeda. Kriteria partisipan dalam penelitian ini adalah laki-laki maupun perempuan, serta memiliki indikasi kecemasan pada tingkat moderate atau high. Kriteria kecemasan menurut Nevid et al. (2005) adalah gelisah, berkeringat, sulit bernafas, jantung berdebar-debar, merasa pusing, mual, perut terasa sakit, mudah marah, menghindari atau bergantung pada orang lain, memiliki ketakutan tanpa disertai alasan yang jelas, serta memiliki pikiran segalanya terasa membingungkan.

\section{Persiapan dan prosedur penelitian}

Peneliti melakukan screening awal dengan menyebarkan kuesioner online yang berisikan identitas, kriteria kecemasan, dan STAI. Kemudian partisipan dipilih apabila memiliki simtom kecemasan dengan tingkat moderate atau high, berusia 18-25 tahun, serta berstatus sebagai mahasiswa suatu universitas. Kemudian peneliti menghubungi partisipan yang memenuhi kriteria untuk mengkonfirmasi akan kesediaan partisipan mengikuti penelitian. Sebelum sesi dimulai secara individual, peneliti selalu menjelaskan terlebih dahulu mengenai prosedur intervensi yang akan dilakukan, juga mengenai komitmen partisipan yang sangat dibutuhkan demi kelancaran penelitian. Selain itu, peneliti juga menjelaskan mengenai perlengkapan yang akan digunakan, menyusun jadwal rutin sesi (memiliki jarak 3 hari antara sesi satu dengan sesi lainnya pada setiap partisipan), serta mengisi kembali STAI pada sesi terminasi.

\section{Desain penelitian}

Penelitian ini menggunakan desain quasi-eksperimen. Hal ini guna melihat dampak diberikannya intervensi tanpa adanya kelompok kontrol. Dampak intervensi dilihat dari perbedaan tingkat kecemasan sebelum dan sesudah diberikan intervensi.

\section{Tempat pelaksanaan}

Penelitian dilaksanakan di rumah masing-masing partisipan menggunakan media daring, zoom.

\section{Perlengkapan penelitian}

Penelitian ini menggunakan perlengkapan seperti informed consent, halaman biodata, kertas A3, cat akrilik, krayon, palette, tisu, pensil, penghapus, kuas, dan wadah (untuk mencuci kuas).

\section{Pengukuran}

Sebelum melakukan intervensi, alat ukur yang digunakan untuk mengukur kecemasan adalah state-trait anxiety inventory (STAI), terdiri dari total keseluruhan 40 butir aitem. 20 butir aitem 
untuk mengukur state anxiety dan 20 butir aitem untuk mengukur trait anxiety. Setiap item pada alat ukur ini diberikan empat (4) pilihan jawaban yang terdiri dari tidak sama sekali (diberikan skor 1), agak (diberikan skor 2), cenderung (diberikan skor 3), dan sangat (diberikan skor 4). Selain itu, alat ukur ini juga memiliki beberapa aitem negatif, sehingga dalam scoring diharuskan untuk mengkonversikan skor tersebut. Skor empat (4) menjadi satu (1), tiga (3) menjadi dua (2), dua (2) menjadi tiga (3), dan satu (1) menjadi empat (4). Cara menghitung alat ukur ini adalah dengan menjumlahkan seluruh skor dengan skor aitem negatif yang sudah dikonversikan. 20-39 kategori low, 40-59 kategori moderate, dan 60-80 kategori high (Hernawaty et al., 2015). Alat ukur ini memiliki angka koefisien reliabilitas sebesar 0.93 untuk state anxiety dan 0.91 untuk trait anxiety, serta validitas sebesar 0.88 (McDowell, 2006).

\section{HASIL DAN PEMBAHASAN}

\section{Gambaran partisipan}

Partisipan dalam penelitian ini terdiri dari enam orang dengan tingkat kecemasan yang beragam. Selain itu, keenam partisipan berjenis kelamin perempuan serta berusia antara 18-25 tahun. Para partisipan sudah menjalani perkuliahan daring selama empat hingga tujuh bulan lamanya. Alasan mereka dapat mengalami kecemasan pun juga beragam satu sama lain.

Tabel 1

Gambaran Partisipan

\begin{tabular}{cccc}
\hline No & Partisipan (nama samaran) & Usia & Jenis Kelamin \\
\hline 1 & Sinta & 21 tahun & Perempuan \\
2 & Sherry & 20 tahun & Perempuan \\
3 & Win & 20 tahun & Perempuan \\
4 & Jes & 20 tahun & Perempuan \\
5 & Angie & 21 tahun & Perempuan \\
6 & Ady & 20 tahun & Perempuan \\
\hline
\end{tabular}

\section{Pelaksanaan intervensi psikologis}

Sesi intervensi dilaksanakan sebanyak dua kali dalam satu minggu dengan jarak tiga hari antar sesi satu dengan sesi lainnya per individu. Keseluruhan proses intervensi diselesaikan dalam waktu satu setengah bulan. Setiap sesi berlangsung kurang lebih antara satu hingga tiga jam (tergantung dari waktu yang digunakan partisipan untuk menyelesaikan gambar yang dibuat). Sesi pertama selalu dimulai dengan free drawing dan dilanjutkan dengan sesi art therapy oleh Ganim (1999).

\section{Tabel 2}

Sesi Art Therapy

\begin{tabular}{cll}
\hline Sesi & \multicolumn{1}{c}{ Kegiatan } & \multicolumn{1}{c}{ Tujuan } \\
\hline 1 & Expressing your emotion through imagery & Memperkenalkan partisipan terhadap art therapy dan \\
& The difference between expressing emotion with & goal-setting \\
& words and images & Individu dapat mengekspresikan diri secara bebas \\
& Free drawing & Individu dapat mengidentifikasi emosi negatif secara \\
& Expressing an emotion verbally & verbal \\
& Expressing an emotion with imagery & Individu dapat menggambarkan emosi negatif dalam
\end{tabular}


2 Expressing your emotion through imagery

Setting your intentions to activate your healing process

Creating artwork of intention

$3 \quad$ Healing the mind

Exploring your emotional nature

Accessing and releasing your stress-producing emotions

Transformation through reenvisioning
Individu mampu mengidentifikasi aspek dalam diri yang ingin disembuhkan

Belajar untuk meningkatkan rasa independen
$4 \quad$ Healing the body

Using your body's wisdom to heal an illness

Discovering the metaphor behind your physical symptoms

Visualizing what your body needs to heal

Seeing yourself as healthy and well
Individu mampu melepaskan emosi negatif Individu mampu mengubah cara dirinya merespon terhadap emosi negatif
Individu mampu mengekspresikan simtom fisik ke dalam bentuk gambar

Individu mampu mengidentifikasi apa yang diperlukan dirinya untuk sembuh

Menimbulkan kesadaran pada individu bahwa energy penyembuhan terdapat di dalam diri sendiri
$5 \quad$ Transformation of the spirit

The rebirth of your divine self
Individu mampu mengubah cara berpikir dan pandangan yang lama dengan sebuah kesadaran yang baru

\section{Hasil intervensi}

Berdasarkan hasil perbandingan pre-test dengan post-test STAI, seluruhan partisipan mengalami penurunan tingkat kecemasan. Kemudian, dapat dilihat berdasarkan tabel 3 bahwa dengan diberikan intervensi dapat mengurangi tingkat kecemasan.

Tabel 3

Perbandingan Tingkat Kecemasan Setelah Mendapatkan Intervensi

\begin{tabular}{lccc}
\hline Kategori & Mean & N & SD \\
\hline Pre-Test & 57,67 & 6 & 7,39 \\
Post-Test & 37,83 & 6 & 5,95 \\
\hline
\end{tabular}

Berdasarkan hasil penelitian, art therapy terbukti dapat mengurangi kecemasan secara signifikan, seperti penelitian yang dibuat oleh Duong, Stargell, dan Mauk (2017). Hal ini diperkuat dengan uji statistik menggunakan SPSS. Berdasarkan hasil analisis paired sample t- test menunjukkan bahwa terdapat perbedaan yang signifikan antara kecemasan sebelum dan sesudah diberikan art therapy $(\mathrm{M}=19,83, \mathrm{SD}=7,73, \mathrm{t}(5)=6.284 ; \mathrm{p}<, 001)$.

Penurunan poin yang paling besar terjadi pada partisipan Jes (33 poin), diikuti oleh Angie (23 poin) dan Sinta (20 poin). Penurunan tersebut menjelaskan bahwa selama proses terapi, mereka cenderung memiliki insight dan kepekaan terhadap dirinya sendiri. Ketiga partisipan yang sebelum menjalani intervensi memiliki tingkat kecemasan paling tinggi di antara partisipan lain dapat menunjukkan bahwa art therapy bermanfaat bagi individu dengan kecemasan yang tinggi. Hal ini sesuai dengan pernyataan Ganim (1999) bahwa art therapy dapat membantu seseorang mengekspresikan emosi terdalam yang sulit diungkapkan dengan kata-kata. 


\section{KESIMPULAN DAN SARAN \\ Kesimpulan}

Berdasarkan hasil penelitian ini, dapat disimpulkan bahwa art therapy dapat mengurangi kecemasan partisipan. Hal ini dibuktikan dengan adanya penurunan skor rata-rata antara hasil pretest dan post-test.

\section{Saran}

Saran bagi institusi yang menjalankan perkuliahan secara daring, maka penelitian ini dapat menjadi landasan untuk mulai lebih memberikan perhatian pada mahasiswa yang mungkin mengalami kecemasan karena menjalani perkuliahan daring. Selain itu, institusi juga dapat lebih mengaktifkan layanan konseling yang berada di institusi.

Saran bagi psikolog, penelitian ini sekiranya dapat menjadi landasan untuk memberikan intervensi art therapy secara daring bagi mahasiswa atau individu yang membutuhkan. Hal ini dikarenakan berdasarkan hasil penelitian didapatkan kehadiran terapis baik secara langsung maupun tidak langsung tetap menurunkan kecemasan pada individu.

Bagi mahasiswa, sekiranya penelitian ini dapat menjadi landasan agar lebih membuka wawasan dalam mencari bantuan profesional apabila dibutuhkan. Hal ini bertujuan agar para mahasiswa/ pelajar dapat menjalani proses pembelajaran dengan lebih baik dan tidak mengambil langkah maladaptif dengan tujuan mengurangi kecemasan yang dirasakan. Bagi penelitian selanjutnya, sekiranya art therapy dapat dilakukan dengan mengambil lebih banyak sampel penelitian agar dapat memperkaya data yang diperoleh.

\section{Ucapan Terima Kasih (Acknowledgement)}

Ucapan terima kasih peneliti tujukan kepada seluruh pihak yang sudah turut berkontribusi dalam terlaksananya penelitian ini, terutama kepada seluruh partisipan yang sudah bersedia mengikuti penelitian ini dari awal hingga akhir, orang tua peneliti, serta pembimbing yang sudah membantu peneliti agar dapat memberikan yang terbaik dalam penelitian ini.

\section{REFERENSI}

Afrianto, D. (2020). Pandemi: Dari kesehatan, ekonomi, hingga politik. https://bebas.kompas.id/baca/riset/2020/07/17/pandemi-dari-kesehatan- ekonomi-hinggapolitik/

Akbar, J. (2020). Perjalanan covid-19 di Indonesia, lebih dari 100.000 kasus dalam 5 bulan. https://www.kompas.com/tren/read/2020/07/28/060100865/perjalanan-pandemi-covid19-di-indonesia-lebih-dari-100.000-kasus-dalam-5?page=all

American Art Therapy Association. (2013). About art therapy. https://arttherapy.org/about-arttherapy/

Duong, K., Stargell, N. A., \& Mauk, G. W. (2017). Effectiveness of coloring mandala designs to reduce anxiety in graduate counseling students. Journal of Creativity in Mental Health, 13(3), 318-330.

Edwards, K. J., Russell, R. K., Hershberger, P., \& Markert, R. J. (2001). Stress, negative social exchange, and health symptoms in university students. Journal of American College Health, 50(2), 75-79.

Ganim, B. (1999). Art and healing: Using expressive art to heal your body, mind, and spirit. Random House International. 
Ibrahim, A. M. (2020). Dampak covid-19 terhadap perekonomian dan kebijakan pemerintah Indonesia. https://sukabumiupdate.com/detail/bale- warga/opini/68505-Dampak-Covid19-Terhadap-Perekonomian-dan-Kebijakan- Pemerintah-Indonesia

Intan, G. (2020). Jokowi: Wabah corona ungkap banyak kekurangan di sektor kesehatan. https://www.voaindonesia.com/a/jokowi-wabah-corona- ungkap-banyak-kekurangan-disektor-kesehatan/5399032.html

Kurnia, K. (2020). Dede: Dampak pandemi covid-19, sektor pariwisata paling kolaps. https://galamedia.pikiran-rakyat.com/news/pr-35564811/dede- dampak-pandemi-covid19-sektor-pariwisata-paling-kolaps

McDowell, I. (2006). State trait anxiety inventory. Oxford University Press.

Nevid, Rathus, \& Greene. (2005). Psikologi abnormal. Erlangga.

Nuryana, A. N. (2020). Dampak pandemi covid-19 terhadap dunia pendidikan. https://kabarpriangan.com/dampak-pandemi-covid-19-terhadap-dunia- pendidikan/

Prayoga, F. (2020). Sederet dampak covid-19 ke sektor perdagangan Indonesia. https://economy.okezone.com/read/2020/06/24/320/2235846/sederet- dampak-covid-19ke-sektor-perdagangan-indonesia

Rappaport, L. (2009). Focusing-oriented art therapy: Accessing the body's wisdom and creative intelligence. Jessica Kingsley.

Schwartz, L. E., Howell, K. H., \& Jamison, L. E. (2018). Effect of time since loss on grief, resilience, and depression among bereaved emerging adults. Death Studies, 42(9), 537547.

Servaty-Seib, H. L., \& Taub, D. J. (2010). Bereavement and college students: The role of counseling psychology. The Counseling Psychologist, 38(7), 947-975.

Spielberger, C. D. (1966). Anxiety and behavior. Academic Press.

Sugihamreta, I. D. G. (2020). Respon kebijakan: Mitigasi dampak wabah covid-19 pada sektor pariwisata. The Indonesian Journal of Development Planning, IV(2), 191-206.

Zuraya, N. (2020). Tiga dampak besar pandemi covid-19 bagi ekonomi RI. https://republika.co.id/berita/qdgt5p383/tiga-dampak-besar-pandemi- covid19-bagiekonomi-ri 